\title{
Determinasi Diri pada Lansia Penghafal Al-Qur'an
}

\author{
FAZA IZZUDDIN NUHA* \\ Fakultas Psikologi Universitas Airlangga
}

\begin{abstract}
ABSTRAK
Penelitian ini bertujuan untuk mengetahui gambaran determinasi diri pada lansia yang menghafalkan Al-Qur'an. Lansia umumnya mengalami degradasi fungsi fisik, kognitif, dan psikososial, namun mereka mampu mengarahkan berbagai upaya untuk menyelesaikan masalah yang dihadapi guna mencapai tujuan. Penelitian ini berjenis kualitatif deskriptif. Partisipan dipilih menggunakan metode purposive sampling dengan teknik analisis tematik. Partisipan dalam penelitian ini berjumlah empat orang dengan usia lebih dari 60 tahun dan sedang atau menghafalkan Al-Qur'an minimal satu juz. Hasil penelitian menunjukkan terdapat perubahan motivasi pada keempat partisipan dan perbedaan gambaran determinasi diri pada keempat partisipan. Determinasi diri yang dimiliki keempat partisipan membantu keberhasilan keempat partisipan menghafalkan Al-Qur'an da mengatasi permasalah yang dihadapi. Dari hasil tersebut menunjukkan bahwa motivasi dan determinasi diri berpengaruh signifikan terhadap keberhasilan kegiatan menghafalkan Al-Qur'an bagi lansia.
\end{abstract}

Kata kunci: determinasi diri, lansia, menghafalkan Al-Qur'an

\begin{abstract}
The aim of this study is to know the overview of self-determination on elderly people who memorize AlQur'an. Elderly people usually have various degradation on their physical, cognitive, and psychosocial function. This study used a qualitative descriptive approach. The participants were selected by using purposive sampling technique based on the criterias. Analysis technique used in this study is the thematic analysis. There were four participants used in this study, all of them are more than 60 years old and were/are trying to memorize Al-Qur'an with a minimum of one juz. The result of the study shows that four participants had some shifting of motivation that once external changed into internal motivation and a different description of self-determination between the participants which helps them to memorize Al-Qur'an and face their obstacle during the process. The result indicated that there is a significant affect of motivation and self-determination on elderly people who memorize Al-Qur'an.
\end{abstract}

Keywords: eldery, memorizing Al-Qur'an, self-determination

Buletin Penelitian Psikologi dan Kesehatan Mental (BRPKM), 2021, Vol. 1(1), 607-620

*Alamat korespondensi: Fakultas Psikologi Universitas Airlangga, Kampus B Universitas Airlangga Jalan

Airlangga 4-6 Surabaya 60286. Surel: faza.izzuddin.nuha-2017@psikologi.unair.ac.id

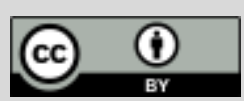

Naskah ini merupakan naskah dengan akses terbuka di bawah ketentuan the Creative Common Attribution License (CC-BY-4.0) (http://creativecommons.org/licenses/by/4.0), sehingga penggunaan, distribusi, reproduksi dalam media apapun atas artikel ini tidak dibatasi, selama sumber aslinya disitir dengan baik. 


\section{PEN D A H U L UA N}

Menghafalkan Al-Qur'an merupakan salah satu kegiatan yang sering dilakukan oleh kaum muslim dan merupakan bagian ritual keagamaan yang penting. Terdapat dua faktor yang memengaruhi seseorang untuk menghafalkan Al-Qur'an, yaitu faktor intrinsik dan ekstrinsik (Rosidi, 2016). Faktor intrinsik meliputi bagaimana seseorang mempersepsikan diri, harapan pribadi, keinginan, kebutuhan, kepuasan, dan harga diri seseorang. Sedangkan faktor ekstrinsik merupakan dorongan dari luar seperti faktor sosial-budaya dan faktor lingkungan budaya (Crow, 1982)

Menurut Wahid (2012), terdapat tiga faktor yang menjadi kunci kesuksesan seseorang dalam menghafalkan Al-Qur'an, yaitu kesehatan fisik, mental, dan tingkat kecerdasan seseorang. Keadaan fisik yang sehat menjadikan seseorang tidak akan terhambat oleh permasalahan yang disebabkan oleh kesehatan ketika menghafalkan Al-Qur'an. Selain kesehatan fisik, kesehatan mental seseorang juga harus dalam keadaan yang sehat, dikarenakan dalam menghafalkan Al-Qur'an dibutuhkan ketenangan, baik hati maupun pikiran. Terakhir adalah tingkat kecerdasan seseorang merupakan komponen utama dalam kegiatan menghafalkan Al-Qur'an. Hal tersebut dikarenakan kemampuan mengulang kembali ayat yang sudah dihafalkan berkaitan dengan kemampuan Associative memory yang dimiliki oleh seseorang (Suryabarata, 1995)

Seseorang yang menghafalkan Al-Qur'an pada usia muda akan memiliki performa yang lebih baik dibandingkan menghafalkan Al-Qur'an pada usia tua. Hal tersebut dikarenakan seiring bertambahnya usia, terjadi penurunan daya ingat dan kualitas intelektual yang disertai dengan gangguan penglihatan (Yatim, 1998). Kesulitan lain yang dihadapi ketika menghafalkan Al-Qur'an di usia tua adalah adanya penurunan kecepatan respon maksimal. Kecepatan respon maksimal terjadi pada usia 20 hingga 25 tahun, sehingga seseorang yang berumur 20-an tahun akan lebih mudah mengikuti arahan dalam belajar ketimbang seseorang berusia 40 tahun keatas (Hurlock, 2002)

Kenyataannya, di sekeliling kita banyak dijumpai lansia yang memiliki keinginan untuk menghafalkan Al-Qur'an. Lansia merupakan bagian dari populasi penduduk yang berumur lebih dari 60 tahun (Bustan, 2007). Para penghafal Al-Qur'an lansia biasanya tergabung dalam suatu organisasi yang memiliki program tahfidz khusus lansia. Kegiatan ini tergolong unik dikarenakan secara teori psikologi perkembangan usia lanjut, lansia pada umumnya mengalami perubahan fisiologis, motorik, dan mental. Perubahan tersebut menyebabkan keterbatasan bagi lansia dalam proses belajar, mengingat, dan mengucapkan kata (Desmita, 2005). Menurut Potter dan Perry (2009), terdapat tiga perubahan yang terjadi ketika seseorang memasuki fase lansia, antara lain perubahan fisiologis, perilaku psikososial, serta kognitif. Pada usia ini juga, seseorang akan mengalami penurunan fungsi sel otak, yang berujung pada pelemahan daya ingat jangka pendek, sulit berkonsentrasi, serta melambatnya proses penerimaan informasi yang berakibat pada kesulitan berkomunikasi (Mubarok dkk., 2010).

Penurunan kondisi fisik yang terjadi akan mengurangi kemampuan lansia dalam menghafalkan AlQur'an. Walaupun para lansia mengalami penurunan dalam kemampuan daya ingat, mereka tetap memiliki keinginan yang kuat untuk menghafal Al-Qur'an. Hal tersebut dapat dikarenakan adanya kemauan, keharusan, ataupun dorongan yang kuat yang dimiliki oleh lansia. Dorongan yang kuat tersebut dapat dikatakan sebagai motivasi yang berasal dari diri mereka untuk menghafal AlQur'an. Terdapat dua jenis motivasi yang menjadi dasar para lansia dalam menghafalkan Al-Qur'an, yaitu motivasi internal dan motivasi eksternal (Hayati dkk., 2018). Motivasi internal adalah motivasi yang berasal dari dalam diri seseorang seperti keinginan para lansia untuk mengisi waktu luang dengan kegiatan yang bermanfaat dan bernilai pahala, memiliki kecintaan terhadap Al-Qur'an, perasaan bahagia saat membaca atau menghafalkannya, keinginan untuk lebih mengingat Allah SWT dalam 
sehari-hari, dan keyakinan akan hari kiamat. Sedangkan motivasi eksternal merupakan motivasi yang berasal dari luar individu, seperti intensitas seseorang dalam melakukan kegiatan yang berkaitan dengan Al-Qur'an (membaca dan menyimak) serta tren hafalan Al-Qur'an yang ada di masyarakat.

Seseorang yang memiliki motivasi saat melakukan suatu tugas maka ia akan mampu melakukan tugasnya dengan baik dan dilakukan dengan mandiri (Ryan, Kuhl, Deci., 1997). Pendapat tersebut juga menekankan bahwa individu dapat lebih atau kurang meregulasi dirinya yang terkait dengan tingkat kepuasan kebutuhan dasar psikologisnya, hal tersebut yang disebut dengan motivasi intrinsik. Tahapan tertinggi dari regulasi diri tersebut berada pada saat seseorang melakukan tindakan yang dilakukan karena orang tersebut tertarik atau merasa penting untuk melakukannya dan tingkat terendah adalah saat seseorang melakukan sesuatu karena dipaksa atau disuruh oleh orang lain (Nurjannah \& Alsa, 2016). Motivasi yang kuat sangat diperlukan oleh para lansia untuk dapat menghafalkan Al-Qur'an di tengah keterbatasan yang dimiliki. Hal tersebut bertujuan agar para lansia dapat selalu gigih dan konsisten menghafalkan Al-Qur'an. Oleh karena itu, diperlukan adanya determinasi diri yang kuat dalam diri lansia untuk menghafalkan Al-Qur'an.

Seseorang tergerak melakukan sebuah tindakan berdasarkan faktor yang berbeda-beda, yang menghasilkan pengalaman dan konsekuensi yang bervariasi pula. Seseorang melakukan sebuah tindakan dikarenakan mereka menghargai dan memiliki minat pada suatu kegiatan tertentu atau adanya paksaan dari luar yang memaksa mereka melakukan hal tersebut. Perbedaan seseorang yang termotivasi dari dalam diri dengan mereka yang termotivasi secara eksternal dalam melakukan sesuatu, ditandai dengan seseorang akan cenderung untuk lebih memiliki minat pada sesuatu, lebih bersemangat, dan lebih percaya diri, yang termanifestasi dalam peningkatan performa kinerja, ketekunan, dan kreativitas dalam melakukan sesuatu (Ryan \& Deci, 1991).

\section{Determinasi diri}

Determinasi diri merupakan kapasitas seseorang dalam menentukan dan memiliki pilihan untuk memilih suatu tindakan atau dapat dikatakan sebagai ketetapan hati seseorang pada suatu tujuan yang hendak dicapainya (Ryan \& Deci, 1985). Menurut Ward (1988) determinasi diri adalah sikap yang mengarahkan seseorang dalam menentukan tujuannya dan kemampuan untuk seseorang berinisiatif dalam meraih tujuannya. Selanjutnya, menurut Powers dkk. (1996) determinasi diri merupakan sikap dan kemampuan individu yang memfasilitasi seseorang dalam mengidentifikasi dan meraih tujuannya. Dalam penelitian ini, yang menjadi fokus guna menyoroti perilaku determinasi diri pada lansia penghafal Al-Qur'an adalah teori determinasi diri yang diperkenalkan oleh Ryan \& Deci (2000).

Dalam teori determinasi diri terdapat tiga komponen yang menjadi kebutuhan psikologis seseorang yaitu autonomy, competence, dan relatedness (Niemiec \& Ryan, 2009). Kebutuhan autonomy mengacu pada kebutuhan untuk mengontrol dan berperilaku mandiri. Selanjutnya, competence atau kompetensi merupakan kemampuan yang dimiliki oleh seseorang untuk mencapai tujuan (Schunk dkk., 2012). Seseorang perlu merasa untuk kompeten dalam berinteraksi dengan orang lain, mengerjakan pekerjaan dan aktivitas dalam konteks yang lebih luas. Kebutuhan akan kompetensi akan mendorong seseorang untuk tertarik pada sesuatu dan belajar dengan lebih giat (Schunk dkk., 2012). Kemudian kebutuhan yang terakhir adalah relatedness atau keterhubungan yang berkaitan dengan hubungan yang hangat seseorang dengan orang lain dalam suatu komunitas atau kelompok yang syarat akan ketergantungan satu dengan yang lain (King, 2010). Berdasarkan beberapa pendapat di atas, maka dapat disimpulkan determinasi diri adalah kapasitas individu yang ditandai dengan komitmen, keyakinan, dan kebulatan tekad dalam mencapai suatu tujuan. Kapasitas ini tumbuh dan berkembang dimotivasi oleh kondisikondisi internal individu, meskipun demikian kondisi di luar individu juga berperan dalam mengokohkan motivasi dan komitmen. 
Teori determinasi diri turut menjelaskan bahwa jenis motivasi yang bersifat eksternal dapat diinternalisasikan ke dalam diri seseorang menjadi sebuah motivasi intrinsik, hal tersebut dikenal sebagai internalisasi motivasi ekstrinsik (LaGuardia, 2009). Secara khusus teori determinasi diri membedakan perubahan motivasi berdasarkan gaya autonomi yang berlaku pada diri seseorang (Grolnick \& Ryan, 2009). Seseorang yang melakukan sebuah tindakan yang bersifat paksaan, cenderung bertindak untuk mendapatkan imbalan atau untuk menghindari hukuman, namun ketika imbalan atau hukuman dihilangkan, perilaku tersebut tidak berjalan dengan baik seperti sebelumnya (LaGuardia, 2009).

Terdapat dua jenis internalisasi motivasi ekstrinsik, yaitu introjeksi dan identifikasi. Perilaku introjeksi biasa digambarkan sebagai sebuah gagasan yang diinternalisasi secara langsung dari orang lain dan tanpa melewati proses regulasi nilai agar sesuai dengan dirinya. Tingkah laku yang timbul dari regulasi yang terintrojeksi mirip seperti tingkah laku seseorang yang diatur secara eksternal dan dikontrol oleh orang lain (Brown dkk., 2009). Sehingga, ketika seseorang berperilaku diatur secara introjeksi, mereka cenderung bertindak untuk menghindari rasa bersalah, menghindari rasa malu, atau untuk mendapatkan pengakuan dan harga diri dari orang lain. Berbeda dengan motivasi yang diregulasi dengan identifikasi, seseorang akan secara sadar menerima serta memaknai nilai dan perilaku tersebut, yang kemudian menuntun seseorang untuk berkomitmen penuh dalam melakukan suatu pekerjaan (LaGuardia, 2009). Sehingga motivasi yang diregulasi dengan teridentifikasi dikaitkan dengan ketekunan dan kinerja yang lebih baik ketimbang perilaku yang dimotivasi secara terintrojeksi (Brown dkk., 2009).

Penelitian terdahulu mengenai determinasi diri pada seting siswa yang mengikuti sebuah bimbingan belajar kimia yang dilakukan oleh Black \& Deci (2000), menunjukkan bahwa siswa yang mengikuti bimbingan belajar dengan motivasi autonomi yang tinggi cenderung memiliki pengalaman yang lebih positif, hal tersebut disangkutkan dengan persepsi kompetensi dan minat yang lebih tinggi serta kecemasan yang lebih rendah. Pada penelitian tersebut pula, sejalan dengan hipotesis bahwa siswa yang mengikuti kegiatan dengan motivasi autonomi yang relatif tinggi akan lebih memilih untuk terus mengikuti kursus dan tidak berhenti. Lebih jauh lagi, siswa yang mengikuti kursus dengan motivasi autonomi yang tinggi mendapatkan nilai yang lebih baik ketimbang siswa dengan motivasi autonomi yang rendah.

Determinasi diri dapat dikatakan sebagai sebuah fenomena yang rumit, yang terdiri dari kemampuan serta pengetahuan dan kontrol yang cukup untuk bertindak atau memutuskan suatu keputusan serta untuk memiliki hukum dan etika (Ekelund dkk., 2014). Sebagaimana disebutkan dalam penelitian Haqiqi (2016), menunjukkan bahwa seseorang yang memiliki determinasi diri yang baik akan melakukan suatu aktivitas dengan disiplin. Berdasarkan penelitian tersebut pula disebutkan bahwa seseorang yang memiliki determinasi diri yang baik mampu mengatur dorongan negatif dari luar sehingga tidak banyak memengaruhi dirinya. Hal tersebut memiliki dampak yang positif bagi seseorang yang sedang menghafalkan Al-Qur'an, dikarenakan disiplin dan mampu menjaga niat dibutuhkan seseorang untuk mempermudah menghafalkan Al-Qur'an (Masduki, 2018). Meskipun penelitian mengenai determinasi diri sudah banyak dilakukan pada berbagai konteks penelitian, namun penelitian yang secara spesifik membahas mengenai determinasi diri pada lansia penghafal Al-Qur'an belum pernah dilakukan sebelumnya. Maka dari itu peneliti berusaha mendeskripsikan determinasi diri pada lansia penghafal Al-Qur'an. 


\section{Desain Penelitian}

\section{E T O D E}

Pada penelitian ini, peneliti membahas tentang determinasi diri pada lansia dalam mencapai tujuannya menghafalkan Al-Qur'an di tengah keterbatasan yang dimiliki. Penelitian ini menggunakan pendekatan kualitatif deskriptif dengan teknik analisis tematik untuk mengelaborasi determinasi diri pada lansia penghafal Al-Qur'an. Pemilihan pendekatan dimaksudkan untuk menggali lebih dalam dan memperoleh gambaran yang lebih jelas mengenai kemandirian, keterhubungan, dan kompetensi lansia dalam menghafal Al-Qur'an.

\section{Partisipan}

Partisipan dalam penelitian ini dipilih menggunakan metode purposive sampling sesuai dengan kriteria yang dibutuhkan, yaitu lansia atau individu berusia 60 tahun ke atas yang sedang berusaha untuk menghafal Al-Qur'an minimal satu juz. Partisipan dalam penelitian ditemukan melalui masjid atau lembaga non-profit di sekitar kota Surakarta. Setelah dilakukan pencarian mengenai majelis pengajian dan pondok hafalan Al-Qur'an, peneliti berhasil menemukan beberapa kandidat partisipan, dari lima kandidat terpilih empat partisipan penelitian yang sesuai dengan karakteristik penelitian. Selanjutnya, peneliti menghubungi partisipan untuk melakukan identifikasi terhadap para lansia yang telah menghafal satu juz Al-Qur'an sekaligus menanyakan kesediaan dari keempat partisipan untuk berpartisipasi dalam penelitian ini. Sebagai bukti kesediaan partisipan untuk berpartisipasi dalam penelitian, partisipan mengisi informed consent yang berisi jabaran dari tujuan penelitian, prosedur pengambilan data, persetujuan partisipan untuk berpartisipasi dalam penelitian, dan penjelasan terkait kerahasiaan informasi yang diberikan oleh partisipan.

\section{Teknik Pengumpulan Data}

Teknik pengumpulan data dalam penelitian ini dilakukan dengan wawancara semi-terstruktur yang selanjutnya akan diorganisasikan menjadi transkrip wawancara dan dianalisis menggunakan teknik analisis tematik (Fereday \& Muir-Cochrane, 2006). Wawancara dilakukan secara daring dikarenakan adanya pandemi COVID-19 yang menjadikan situasi tidak memungkinkan untuk terjadi kontak secara langsung dengan partisipan.

\section{Analisis Data}

Teknik analisis data yang dilakukan pada penelitian ini menggunakan analisis tematik (Fereday \& MuirCochrane, 2006). Adapun urutan dalam melakukan analisis tematik adalah sebagai berikut: (1) Pengembangan kode manual, yaitu pemberian kode secara manual pada temuan data, (2) uji realibilitas kode, yaitu menguji apakah kode dapat diaplikasikan pada data mentah, (3) meringkas data dan menentukan tema awal bertujuan untuk memahami informasi agar peneliti memahami data yang sedang diproses, (4) penerapan kode yaitu memberikan kode pada temuan data yang memiliki makna, (5) menghubungkan kode dan mengidentifikasi tema yaitu identifikasi temuan penelitian yang berkaitan dengan pertanyaan penelitian, (6) kode tema yang mendukung dan menguatkan yaitu pengelompokan lebih lanjut pada tema yang sudah teridentifikasi. Pemantapan kredibilitas pada penelitian ini menggunakan teknik Member check untuk mengetahui sinkronisasi data antara peneliti dengan partisipan maksudkan (Sugiyono, 2007), dengan meminta partisipan untuk mengecek hasil interpretasi data yang dilakukan oleh peneliti. 


\section{HAS I L P E N ELIT I A N}

\section{Motivasi Partisipan Menghafalkan Al-Quran}

\section{Partisipan FF}

Partisipan F menyatakan bahwa motivasi ia menghafalkan Al-Qur'an awalnya karena ingin mendapatkan ridho dari Allah SWT dan ingin menghadiahkan kedua orang tuanya yang sudah meninggal dengan mahkota di akhirat. Namun dalam prosesnya menghafalkan Al-Qur'an, partisipan F mampu menemukan manfaat selain motivasi utama yang partisipan inginkan, antara lain hati yang tenang, kebutuhan yang selalu tercukupi, peningkatan kualitas kesehatan dan partisipan mampu memberikan dampak pada lingkungan tempat tinggalnya. Beberapa manfaat tersebutlah menjadikan partisipan F melanjutkan aktivitas menghafalkan Al-Qur'an meskipun terdapat kendala yang dihadapi dalam menghafal dan menjaga hafalan yang sudah ia miliki.

\section{Partisipan $W W$}

Partisipan WW yang awalnya menghafalkan Al-Qur'an dikarenakan mendapatkan ajakan dari temantemannya yang sejatinya merupakan motivasi eksternal berubah setelah merasakan manfaat dari menghafalkan Al-Qur'an. Manfaat yang dirasakan oleh partisipan WW antara lain hati yang lebih tenang dan teman-teman yang baik yang menjadikan partisipan merasa nyaman di sekitar teman-temannya. Lingkungan sekitar partisipan yang mendukung bagi perkembangan partisipan WW, menjadikan partisipan WW mampu menginternalisasikan motivasi yang bersifat lebih autonomi bagi kegiatan menghafalkan Al-Qur'an sehingga menjadikan partisipan WW selalu termotivasi untuk menghafalkan Al-Qur'an.

\section{Partisipan MI}

Latar belakang keluarga partisipan MI yang merupakan keluarga agamis menjadikan partisipan MI merasa dirinya harus menghafalkan Al-Qur'an agar sesuai dengan pesan yang diberikan oleh kakek partisipan MI bahwa semua anak keturunannya harus menjadi seorang guru mengaji. Selain itu, partisipan MI menyatakan bahwa ia menghafalkan Al-Qur'an dikarenakan kewajiban sebagai seorang muslim. Seiring berjalannya waktu partisipan MI menghafalkan Al-Qur'an, menuntunnya menemukan alasan lain untuk terus menghafalkan Al-Qur'an. Di samping tujuan awal partisipan menghafalkan AlQur'an, yaitu ketenangan hati dan rezeki yang terus mengalir.

\section{Partisipan $N$}

Partisipan $\mathrm{N}$ menyatakan bahwa alasan ia menghafalkan Al-Qur'an dikarenakan partisipan ingin memanfaatkan waktu yang ia miliki sebelum meninggal untuk memahami Al-Qur'an dan salah satu upaya yang partisipan usahakan adalah dengan menghafalkan Al-Qur'an. Partisipan N membuktikan bahwa ia mampu lebih memahami Al-Qur'an melalui metode menghafalkan yang ia gunakan, yaitu dengan memahami arti dari setiap ayat yang akan dihafalkan sehingga akan menambah pengetahuan partisipan $\mathrm{N}$ seputar agama Islam. Di samping pengetahuan agama Islam infoman $\mathrm{N}$ bertambah, ia juga merasakan bahwa dengan menghafalkan Al-Qur'an dapat menguatkan daya ingatnya, sehingga ia tidak mudah menjadi lupa. Kedua hal tersebut yang menjadikan partisipan menikmati kegiatan menghafalkan Al-Qur'an. 
Gambaran Determinasi Diri Lansia Penghafal Al-Quran

\section{Autonomy}

Determinasi diri pada dimensi autonomy yang dimiliki oleh keempat partisipan memiliki beberapa persamaan, yaitu keinginan partisipan untuk menghafalkan Al-Qur'an berasal dari diri sendiri, meskipun motivasi yang melandasi keinginan masing-masing partisipan untuk menghafalkan Al-Qur'an berbeda-beda. Tingkat autonomi yang tinggi ditunjukkan oleh keempat partisipan dengan usaha mereka untuk menghafalkan Al-Qur'an. Partisipan $\mathrm{F}$ dan $\mathrm{N}$ harus mengikuti karantina di tempat yang jauh dari rumah mereka untuk bisa menghafalkan Al-Qur'an, sedangkan partisipan WW harus menempuh jarak 7 kilometer dengan sepeda motor dua kali seminggu untuk bisa menghafalkan AlQur'an. Selain itu keempat partisipan meluangkan waktu setiap hari untuk menjaga hafalan yang mereka miliki agar tidak hilang. Tingkat autonomi yang tinggi tersebut dipengaruhi oleh regulasi motivasi menghafalkan Al-Qur'an yang tumbuh dari hasil identifikasi nilai dan makna dari kegiatan menghafalkan Al-Qur'an.

Partisipan WW menghafalkan Al-Qur'an berawal dari ajakan temannya. Dalam perjalanan partisipan menghafalkan Al-Qur'an, partisipan mampu menginternalisasikan motivasi yang awalnya bersifat eksternal menjadi internal, hal tersebut dikarenakan partisipan menyadari bahwa menghafalkan AlQur'an memiliki banyak manfaat yang bisa didapatkan, seperti menjadikan dirinya lebih sehat dan mendapatkan ketenangan hati.

Hal yang sama juga terjadi pada partisipan MI yang mampu menginternalisasikan bahwa menghafalkan Al-Qur'an merupakan kewajiban dan tanggung jawab seorang muslim yang sejatinya merupakan sebuah motivasi eksternal menjadi sebuah motivasi internal untuk menghafalkan Al-Qur'an. Hal tersebut dikarenakan partisipan mampu menemukan manfaat lain selain tujuan awal partisipan MI dalam menghafalkan Al-Qur'an.

Partisipan F dan N pada mulanya menghafalkan Al-Qur'an dikarenakan memiliki banyak waktu luang setelah mereka menjadi seorang pensiunan. Namun pada proses menghafalkan Al-Qur'an, kedua partisipan menemukan manfaat lain selain tujuan awal mereka. Partisipan F, mengaku setelah menghafalkan Al-Qur'an merasakan peningkatan kualitas kesehatan dan ketenangan hati, yang menjadikan partisipan F berkomitmen dalam menghafalkan Al-Qur'an. Sedangkan pada partisipan N, selain untuk mengisi waktu luang, ia juga memiliki kemauan untuk memperdalam ilmu agama yang ia dapatkan seiring proses menghafalkan Al-Qur'an.

\section{Competence}

Determinasi diri partisipan F, WW, MI, dan N pada dimensi competence memiliki beberapa kesamaan satu sama lain. Dimensi competence keempat partisipan ditunjukkan dengan keinginan mereka untuk menghafalkan Al-Qur'an sebanyak dan sebaik mungkin sehingga menjadikan mereka dapat bermanfaat bagi lingkungan sekitar. Partisipan F dan N yang memiliki latar belakang tafsir bahasa Arab yang mereka miliki, menjadikan mereka lebih mudah dalam menghafalkan Al-Qur'an. Berbeda dengan partisipan $\mathrm{F}$ dan $\mathrm{N}$ yang memiliki latar belakang tafsir Al-Qur'an, partisipan WW dan MI menghafalkan Al-Qur'an dengan mengulang-ulang ayat Al-Qur'an yang akan mereka hafalkan, mereka meyakini dengan melakukan hal tersebut akan memudahkan mereka untuk menghafalkan Al-Qur'an.

Manfaat yang bisa partisipan F berikan bagi lingkungannya adalah menjadi pengurus sekaligus pengajar di taman pendidikan Al-Qur'an di sekitar rumahnya dan sewaktu salat berjamaah partisipan F dapat membenarkan bacaan ayat Al-Quran imam yang salah. Partisipan MI dapat mendirikan sebuah pondok pesantren di Bilangan, Kota Klaten. Selain itu partisipan MI juga menjadi pembimbing pengajian lansia

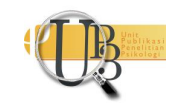


di daerah tempat tinggalnya. Partisipan MI dan N juga rutin menjadi imam salat di masjid lingkungan rumah mereka. Sehari-hari partisipan MI dan N mampu membimbing keluarga terkait dengan pemahaman Al-Qur'an berkat kemampuan mereka dalam menghafalkan Al-Qur'an.

\section{Relatedness}

Determinasi diri partisipan dari dimensi relatedness pada partisipan $\mathrm{F}, \mathrm{WW}, \mathrm{MI}$, dan $\mathrm{N}$ memiliki kesamaan antara satu sama lain. Partisipan F menyatakan bahwa dukungan dari keluarga dan orang sekitar partisipan saat partisipan mengikuti karantina di Siwatu menjadikan partisipan bersemangat dalam menghafalkan Al-Qur'an. Partisipan F mengatakan bahwa ia merasa memiliki cucu baru dari santri lain yang berumur jauh lebih muda dari pada partisipan F. Tidak berbeda dengan partisipan F, partisipan WW merasa bahagia mendapatkan teman-teman baru yang saling mendukung satu sama lain dan memiliki tujuan yang sama dengannya, menjadikan partisipan WW selalu bersemangat dalam menghafalkan Al-Qur'an.

Hal yang sama dirasakan oleh partisipan MI, dukungan yang diberikan oleh anggota keluarganya menjadikan partisipan MI dan keluarga tidak mengenal kata lelah untuk mendalami ilmu agama khususnya menghafalkan Al-Qur'an, selain ia merasakan manfaat dari dukungan keluarganya, partisipan MI juga merasakan manfaat dari anggota pengajian yang ia bina menjadikannya selalu bersemangat untuk terus berproses menghafalkan Al-Qur'an. Berbeda dengan partisipan ketiga partisipan lainnya, Partisipan N mengungkapkan bahwa dukungan orang terdekat yaitu istri dan anaknya sudah cukup baginya untuk membuatnya bersemangat dalam menghafalkan Al-Qur'an.

\section{Kendala dalam Menghafalkan Al-Qur'an dan Cara Mengatasinya}

Perubahan fisik maupun non-fisik yang terjadi pada keempat partisipan memengaruhi masing-masing partisipan dalam menghadapi dinamika menghafalkan Al-Qur'an yang berbeda-beda. Salah satu perubahan yang terjadi karena penuaan adalah melemahnya memori dan ketahanan fisik dari partisipan F, WW, \& MI. Terdapat perbedaan penurunan kinerja pada masing-masing partisipan, partisipan F mengungkapkan umurnya yang sudah tidak muda lagi menjadikannya mudah lelah dan mudah lupa, sehingga partisipan $\mathrm{F}$ harus berhati-hati dalam menjaga kesehatan dan rutin mengulang hafalan yang dimiliki agar tidak mudah hilang. Sedikit berbeda dengan partisipan F, partisipan WW mengungkapkan umurnya yang sudah lanjut menjadikan partisipan WW kesulitan dalam menghafalkan Al-Qur'an dan mudah merasa kantuk saat melakukan aktivitas, adanya kesulitan tersebut menjadikan partisipan WW membutuhkan waktu cenderung lebih lama untuk menghafalkan Al-Qur'an. Penurunan memori juga turut dirasakan oleh partisipan MI yang mengaku mudah lupa meluangkan waktu untuk menghafalkan Al-Qur'an di tengah kesibukan yang ia lakukan. Berbeda dengan ketiga partisipan di atas, partisipan $\mathrm{N}$ tidak merasakan penurunan kualitas memori, namun partisipan $\mathrm{N}$ menyatakan bahwa kesulitan yang dihadapi karena sudah berusia lanjut adalah tidak bisa meninggalkan keluarga untuk dapat fokus menghafalkan Al-Qur'an.

\section{I S K U S I}

\section{Perubahan motivasi}

Motivasi menjadi hal utama yang mendorong para partisipan untuk memaksimalkan potensi yang mereka miliki untuk menghafalkan Al-Qur'an di tengah keterbatasan. Kegiatan menghafalkan Al-Qur'an merupakan salah satu wujud keinginan seseorang untuk terus maju dan berkembang. Kecenderungan tersebut berasal dari motivasi intrinsik, rasa keingintahuan dan kebutuhan-kebutuhan dasar psikologis 
lainnya (Reeve, 2012). Perilaku yang termotivasi secara intrinsik merupakan bentuk dasar dari dimensi autonomy (Black \& Deci, 2000). Pada penelitian ini, motivasi intrinsik mengacu pada nilai-nilai spiritual yang dipegang teguh oleh keempat partisipan yang akhirnya menuntun mereka menghafalkan AlQur'an di usia mereka yang tidak lagi muda.

Pada keempat partisipan terdapat perubahan motivasi yang awalnya bersifat ekstrinsik menjadi sebuah motivasi intrinsik. Perubahan motivasi yang terjadi dikarenakan keempat partisipan memperoleh manfaat selain dari motivasi awal mereka menghafalkan Al-Qur'an. Perubahan jenis motivasi dari eksternal menjadi internal menjadikan keempat partisipan dapat lebih menikmati dan menghayati kegiatan menghafalkan Al-Qur'an. Hal tersebut sesuai dengan LaGuardia (2009), seseorang yang merubah jenis motivasinya dari eksternal menjadi internal akan cenderung melakukan suatu kegiatan dengan lebih memaknai dan menikmati kegiatan yang dilakukan, dan menjadikan seseorang berkomitmen penuh dalam melakukan kegiatannya.

Faktor intrinsik yang dimiliki keempat partisipan diwujudkan dengan alasan mereka menghafalkan AlQur'an yang berorientasi pada kepuasan internal, di mana mereka meyakini bahwa apa yang mereka lakukan merupakan hal yang baik dalam agama Islam. Mereka juga mendapatkan beberapa manfaat yang bisa mereka rasakan seperti kesehatan dan ketenangan hati. Hal tersebut menunjukkan kecenderungan bahwa keempat partisipan memahami bagaimana mereka mempersepsikan diri, apa saja keinginan dan kebutuhan mereka, serta apa saja yang menjadi harapan bagi diri mereka (Crow, 1982).

Performa yang lebih baik ditunjukkan keempat partisipan dengan pengalaman yang positif selama menghafalkan Al-Qur'an, seperti perasaan yang lebih tenang, minat menghafalkan yang tinggi dan hasil yang lebih maksimal. Penelitian Vallerand dkk. (2008), menyebutkan bahwa motivasi yang bersifat determinasi tinggi pada seseorang akan menghasilkan output yang maksimal pada suatu kegiatan, sedangkan motivasi yang kurang bersifat determinasi diri akan cenderung mendapatkan hasil yang tidak maksimal. Hasil yang maksimal dibuktikan keempat partisipan dengan banyaknya jumlah dan kualitas hafalan yang diperoleh, partisipan F mampu menghafalkan Al-Qur'an sebanyak tiga puluh juz dalam waktu tiga bulan, partisipan WW mampu menghafalkan Al-Qur'an sebanyak satu juz selama dua tahun belakang, partisipan MI mampu menghafalkan Al-Qur'an sebanyak tiga juz selama satu tahun, dan partisipan N mampu menghafalkan Al-Qur'an sebanyak sepuluh juz dalam waktu satu bulan.

\section{Gambaran Determinasi diri}

Gambaran determinasi diri pada masing-masing partisipan dapat terlihat dari dimensi determinasi diri, yaitu autonomy, competence, dan relatedness. Dimensi autonomy adalah bagaimana kebutuhan seorang individu dapat mengontrol dan berperilaku mandiri dalam lingkungan ia berinteraksi. Gambaran dimensi autonomy pada keempat partisipan memiliki kesamaan antara satu sama lain. Kesamaan tersebut ditunjukkan dengan keinginan yang berasal dari diri keempat partisipan untuk menghafal dan menjaga hafalan yang telah dimiliki. Keinginan menghafalkan dan menjaga hafalan Al-Qur'an tersebut muncul dari perubahan motivasi yang terjadi dikarenakan keempat partisipan mampu mengubah motivasi ke arah yang lebih optimal dan menuntun mereka menemukan motivasi yang lebih berkelanjutan bagi aktivitas menghafalkan Al-Qur'an. Motivasi yang lebih optimal ditunjukkan keempat partisipan, bahwa mereka tidak hanya termotivasi menghafalkan Al-Qur'an karena imbalan berupa pahala saja, namun terdapat perasaan tergantung pada Al-Qur'an dan perasaan puas serta tenang apabila mereka menghafalkan Al-Qur'an. Hal tersebut menunjukkan bahwa kegiatan menghafalkan AlQur'an yang mereka lakukan berasal dari motivasi internal keempat partisipan, bukan berasal dari motivasi eksternal yang memaksa keempat partisipan untuk menghafalkan dan menjaga hafalan AlQur'an yang mereka miliki. 
Dalam salah satu sub teori determinasi diri, yaitu causality orientation theory (Ryan \& Deci, 1985), menyebutkan bahwa seseorang yang memiliki orientasi autonomi yang tinggi dalam melakukan suatu kegiatan, melihat kebutuhan dan nilai yang mereka miliki sebagai suatu dorongan yang menggerakkan perilaku mereka. Hal tersebut sesuai dengan hasil penelitian ini bahwa kebutuhan mereka akan perasaan tenang, kesehatan yang baik, dan rezeki yang lancar serta nilai terhadap nilai-nilai agama Islam menjadi penggerak utama dalam kegiatan menghafalkan Al-Qur'an. Begitu pula terkait dukungan yang diberikan pada pembimbing dapat meningkatkan autonomi partisipan (Black \& Deci, 2000), hal tersebut serupa dengan temuan pada penelitian ini bahwa dukungan autonomi yang diberikan oleh pembimbing pengajian dapat meningkatkan autonomi partisipan (WW).

Pada gambaran determinasi diri pada dimensi competence terdapat kesamaan antara keempat partisipan, yaitu keinginan untuk menghafalkan Al-Qur'an sesuai dengan kaidah menghafalkan AlQur'an yang baik dan benar. Ryan, Deci, \& Kasser (1997), menyebutkan bahwa bentuk kebutuhan seseorang akan kompetensi diwujudkan dengan tingginya intensitas keterlibatan seseorang pada kegiatan yang syarat akan tantangan, dengan atau tanpa dorongan atau tekanan. Hal tersebut sesuai dengan salah satu alasan yang dituturkan oleh partisipan F dan N menghafalkan Al-Qur'an dikarenakan keinginan untuk memiliki kegiatan yang terprogram dan menggunakan kemampuan tafsir bahasa Arab mereka.

Kesungguhan keempat partisipan untuk menghafalkan Al-Qur'an diwujudkan dengan mereka menghafalkan sesuai dengan hukum bacaan dan pelafalan yang baik. Partisipan F dan WW menyatakan bahwa mereka memerlukan waktu satu tahun untuk mengulang hafalan mereka agar sesuai dengan kaidah yang berlaku, hal tersebut menunjukkan kesungguhan mereka untuk menghafalkan Al-Qur'an yang tinggi. Hal yang sama juga terjadi pada partisipan $\mathrm{F}$ dan $\mathrm{N}$ yang dapat mempraktekan ilmu tafsir bahasa Arab yang ia miliki untuk menghafalkan Al-Qur'an, yang membuktikan bahwa ketika mereka menghafalkan Al-Qur'an terdapat pemaksimalan potensi yang telah dimiliki oleh partisipan $\mathrm{F}$ dan $\mathrm{N}$. Partisipan F, MI, dan N dapat memanfaatkan hafalan Al-Qur'an yang mereka miliki untuk dapat bermanfaat di lingkungan tempat tinggal mereka, seperti partisipan $\mathrm{F}$ yang menjadi ketua taman pengajian Al-Qur'an sekaligus pengajar di sekitar rumahnya, partisipan MI yang dapat mendirikan pondok pesantren dan menjadi pengajar di majelis pengajian di dekat rumahnya, dan partisipan $\mathrm{N}$ yang dapat menjadi imam di masjid di lingkungan rumahnya.

Gambaran dimensi relatedness dari determinasi diri pada keempat partisipan menunjukkan bahwa mereka merasa lebih dekat dengan Allah SWT setelah melakukan kegiatan menghafal Al-Qur'an. Perasaan tersebut menjadikan keempat partisipan mampu meningkatkan kesadaran diri mereka yang diwujudkan dengan rutin memantau perkembangan diri. Perkembangan diri dari keempat partisipan tersebut ditemukan bahwa mereka merasakan adanya peningkatan pada aspek kesehatan dan ketenangan hati. Hal tersebut sejalan dengan penelitian yang dilakukan oleh Sustring \& Wijaya (2019), bahwa interaksi yang terjadi antara seseorang dengan Al-Qur'an dapat menjadikan hati lebih tenang dan seseorang akan lebih mampu mengatur perasaan gelisahnya. Pengaruh teman sebaya pada kegiatan menghafalkan Al-Qur'an turut memberikan dampak yang signifikan bagi kelangsungan kegiatan menghafalkan Al-Qur'an. Seperti pernyataan yang dinyatakan oleh partisipan WW dan MI yang menyebutkan bahwa teman-teman sebaya di pengajian membantu partisipan untuk terus bersemangat dan tetap teguh untuk menghafalkan Al-Qur'an. Hal tersebut sesuai dengan penelitian yang dilakukan oleh Murcia, dkk. (2008) bahwa adanya motivasi yang diberikan oleh teman sebaya pada sebuah tugas akan mempermudah pemenuhan tiga kebutuhan psikologis dasar seseorang. Pada lingkungan tersebut, secara intrinsik partisipan akan merasa termotivasi oleh aktivitas yang dilakukan oleh teman-temanya dan mereka akan melakukan aktivitas tersebut untuk merasakan kebahagiaan dan kesejahteraan. 


\section{Kendala dan cara mengatasinya}

Kendala yang dihadapi oleh masing-masing partisipan pun memiliki kemiripan antara satu dengan yang lain. Umumnya kesulitan yang dialami dikarenakan usia keempat partisipan yang sudah lanjut, seperti sulit untuk menghafalkan, mudah mengantuk, mudah lupa, dan mudah lelah. Kesulitan yang dialami oleh keempat partisipan merupakan hal alami yang terjadi pada seseorang lansia. Menurut Fatmah (2010), secara alami seorang lansia akan mengalami penurunan fungsi dan kemampuan tubuh, penurunan fungsi meliputi fisik, mental, spiritual, dan psikososial (Azizah, 2011).

Banyak cara yang keempat partisipan upayakan untuk mengatasi kesulitan dalam menghafalkan AlQur'an, seperti partisipan F menghadapi kesulitan seperti mudah lelah dan mudah lupa dengan mengalokasikan waktu untuk mengulang hafalan setiap harinya dan tidur diawal malam agar mendapatkan istirahat yang cukup setiap harinya. Selanjutnya, partisipan WW yang menangani kesulitan untuk menghafalkan Al-Qur'an dengan mengulang-ulang ayat yang akan dihafalkan sampai ia mudah mengingatnya, serta senantiasa mengikuti pengajian agar mendapatkan bantuan profesional untuk menghafalkan Al-Qur'an. Bagi partisipan WW, mengikuti pengajian sangat berarti banyak baginya, ia dapat bertemu dengan teman-temannya yang akan menambah semangatnya untuk menghafalkan Al-Qur'an, bertemu dengan teman-temannya juga menjadikan partisipan tidak mudah mengantuk seperti saat ia menghafalkan Al-Qur'an di rumah. Lain halnya dengan partisipan MI, ia mengaku tidak memiliki kesulitan selain kesulitan mengatur waktu di sela-sela kesibukannya untuk menambah dan mengulang hafalan yang ia miliki. Cara yang partisipan MI lakukan adalah dengan menetapkan waktu setiap harinya untuk menambah dan mengulang hafalan yang ia miliki dan apabila ia tidak dapat melakukannya di hari tersebut partisipan MI akan menggantinya pada hari yang lain.

\section{S I M P U L A N}

Motivasi yang mendasari para partisipan untuk menghafalkan Al-Qur'an pada awalnya adalah keinginan individu untuk memperoleh pahala, yang merupakan sebuah motivasi eksternal. Selanjutnya motivasi eksternal tersebut diinternalisasikan ke dalam diri keempat partisipan dikarenakan partisipan merasa dengan menghafalkan Al-Qur'an banyak manfaat yang didapatkan. Sehingga menuntun keempat partisipan untuk menghafalkan Al-Qur'an dengan motivasi yang berasal dari dalam diri.

Determinasi diri para lansia penghafal Al-Qur'an digambarkan melalui tiga dimensi yaitu: autonomy, competence, \& relatedness. Gambaran dimensi autonomy pada keempat partisipan memiliki kesamaan yang ditunjukkan dengan kesungguhan dan kemandirian dalam menghafal dan menjaga hafalan AlQur'an. Pada dimensi competence terlihat dari keinginan keempat partisipan untuk menghafalkan AlQur'an sesuai dengan kaidah menghafalkan Al-Qur'an yang baik dan benar. Sedangkan pada dimensi relatedness, keempat partisipan mengaku merasa lebih dekat dengan Allah SWT setelah melakukan kegiatan menghafal Al-Qur'an dan merasakan keterhubungan yang erat antara para penghafal satu dengan lainnya.

Mayoritas rintangan yang dialami oleh keempat partisipan diakibatkan oleh penurunan kondisi fisik yang sudah tua, antara lain: penurunan kualitas memori, mudah mengantuk, dan mudah lelah. Cara yang ditempuh untuk masing-masing partisipan untuk mengatasi permasalahan tersebut diantaranya: menjaga kesehatan fisik, menjaga pola tidur, mengkonsumsi kopi untuk mencegah kantuk, rajin mengulang-ulang hafalan agar tidak melupakan ayat yang sudah dihafalkan, dan berintrospeksi diri, serta memahami makna ayat Al-Qur'an agar terus termotivasi dalam menghafalkan Al-Qur'an. 


\section{U C A P A N T E R I MAKASIH}

Faza Izzuddin Nuha berterima kasih kepada partisipan yang berpartisipasi dalam penelitian ini sehingga penelitian dapat terselesaikan. Serta berbagai pihak yang telah mendukung kelancaran jalannya penelitian.

\section{DEKLARASI POTENSI TERJADINYA KONFLIK KEPENTINGAN}

Faza Izzuddin Nuha tidak bekerja, menjadi konsultan, memiliki saham, atau menerima dana dari perusahaan atau organisasi manapun yang mungkin akan mengambil untung dari diterbitkannya naskah ini.

\section{PUSTAKA ACUAN}

Azizah, L. M. (2011). Keperawatan Lanjut Usia. Graha Ilmu.

Black, A. E., \& Deci, E. L. (2000). The Effects of Instructors' Autonomy Support and Students' Autonomous Motivation on Learning Organic Chemistry: A Self-Determination Theory Perspective. Science Education, 84(6), 756. https://doi.org/10.1002/1098-237X(200011)84:6<740::AIDSCE4>3.0.CO;2-3

Brown, K. W., Ryan, R. M., \& Weinstein, N. (2009). A multi-method examination of the effects of mindfulness on stress attribution, coping, and emotional well-being. Journal of Research in Personality, 43, 374-385. https://doi.org/10.1016/j.jrp.2008.12.008

Bustan, M. N. (2007). Epidemiologi Penyakit Tidak Menular. Rineka Cipta.

Crow, L. D. (1982). An Outline as General Psychology. New York: Littlefield Adam and Co.

Desmita. (2005). Psikologi Perkembangan. Remaja Rosdakarya.

Ekelund, C., Dahlin-ivanoff, S., \& Eklund, K. (2014). Self-determination and older people - A concept analysis. Scandinavian Journal of Occupational Therapy, 116-124. https://doi.org/10.3109/11038128.2013.853832

Fatmah. (2010). Gizi Usia Lanjut. Erlangga.

Fereday, J., \& Muir-Cochrane, E. (2006). Demonstrating Rigor Using Thematic Analysis: A Hybrid Approach of Inductive and Deductive Coding and Theme Development. International Journal of Qualitative Methods, 5(1), 80-92. https://doi.org/10.1177/160940690600500107

Grolnick, W. S., \& Ryan, R. M. (2009). Parent Styles Associated with Children's Self-Regulation and Competence in School. Journal of Educational Psychology, 81(2), 90-104. https://doi.org/10.1037/0022-0663.81.2.143 
Haqiqi, A. R. (2016). Pengaruh Determinasi Diri Terhadap Kedisipilinan Mahasiswa Tahun Pertama dalam Mengikuti Kegiatan di Mabna Ibnu Sina Pusat Mahad Al-Jami'ah. Disertasi. UIN Malik Ibrahim.

Hayati, Nurhasanah, \& Yusra, O. (2018). Fenomena Lansia Menghafal Al-Quran pada Majelis Al-Quran di Kec. Salimpaung Kab. Tanah Datar Sumatera Barat. Fuaduna, 2(2), 63-72. https://doi.org/10.30983/fuaduna.v2i2.2067

Hurlock, E. B. (2002). Psikologi Perkembangan (Vol. 5). Erlangga.

King, L. A. (2010). Psikologi Umum Sebuah Pandangan Apresiatif. Salemba Humanika.

LaGuardia, J. G. (2009). Developing Who I Am: A Self-Determination Theory Approach to the Establishment of Healthy Identities. Educational Psychologist, 44(2), 90-104. https://doi.org/10.1080/00461520902832350

Masduki, Y. (2018). Implikasi Psikologis Bagi Penghafal Al-Qur'an. Medina-Te, 18(1), Article 1.

Mubarok, W. I., Nurul, C., \& Bambang, A. S. (2010). Ilmu Keperawatan Komunitas: Konsep dan Aplikasi (Vol. 2). Salemba Medika.

Murcia, J. A., Roman, M. L., Galindo, C. M., Alonso, N., \& Gonzalez-Cutre, D. (2008). Peers' Influence on Exercise Enjoyment: A Self-Determination Theory Approach. Journal of Sports Science and Medicine, 7, 23-31. https://doi.org/PMC3763348

Niemiec, C. P., \& Ryan, R. M. (2009). Autonomy, competence, and relatedness in the classroom Applying self-determination theory to educational practice. Theory and Research in Education, 7(2), 133144. https://doi.org/10.1177/1477878509104318 Article information

Nurjannah, S. Y., \& Alsa, A. (2016). Peranan Kepuasan Kebutuhan Dasar Psikologis dan Orientasi Tujuan Mastery Approach terhadap Belajar Berdasar Regulasi Diri. Jurnal Psikologi, 43(2), 85-106. https://doi.org/0.22146/jpsi.22856

Potter, P. A., \& Perry, A. G. (2009). Fundamental Keperawatan: Konsep, proses, dan praktik (Vol. 7). Salemba Medika.

Powers, L. E., Sowers, J., Turner, A., Nesbitt, M., Knowles, A., \& Ellison, R. (Eds.). (1996). On the road to autonomy: Promoting self-competence for children and youth with disabilities. In Take Charge: $A$ model for promoting selfdetermination among adolescents with challenges (pp. 291-332). Brooks.

Reeve, J. (2012). A Self-determination Theory Perspective on Student Engagement. In Handbook of Research on Student Engagement, 149-172. https://doi.org/10.1007/978-1-4614-2018-7_7

Rosidi, A. (2016). Motivasi Santri dalam Mengahfalkan Al-Quran (Studi Multi Kasus di Pondok Pesantren Ilmu Al-Quran (PPIQ) PP. Nurul Jadid Paiton Probolinggo, dan Pondok Pesantren Tahfizhul AlQuran Raudhatusshalihin Wetan Pasar Besar Malang. Al-Qodiri: Jurnal Pendidikan, Sosial, Dan Keagamaan, 53-82. https://doi.org/10.1234/al\%20qodiri.v10i1.1656

Ryan, R. M., \& Deci, E. L. (1985). Intrinsic Motivation and Self-Determination in Human Behavior. Springer Science \& Business Media. 
Ryan, R. M., \& Deci, E. L. (1991). A motivational approach to self: Integration in personality. Nebraska Symposium on Motivation, 38, 237-288.

Ryan, R. M., \& Deci, E. L. (2000). Self-Determination Theory and the Facilitation of Intrinsic Motivation, Social Development, and Well Being. Social Development, and Well Being, 55(1), 66-78. https://doi.org/10.1037/0003-066X.55.1.68

Ryan, R. M., Deci, E. L., \& Kasser, T. (1997). Self-Determined Teaching: Opportunities and Obstacles. The Johns Hopkins University Press.

Ryan, R. M., Kuhl, J., \& Deci, E. L. (1997). Nature and Autonomy: An Organizational View of Social and Neurobiological Aspects of Self-Regulation in Behavior and Development. Development and Psychopathology, 701-728. https://doi.org/10.1017/s0954579497001405

Schunk, D. H., Meece, J. L., \& Pintrinch, P. R. (2012). Motivasi dalam Pendidikan: Teori, Penelitian, dan Aplikasi (Vol. 3). Index.

Sugiyono. (2007). Memahami Penelitian Kualitatif dan R\&D. Alfabeta.

Suryabarata, S. (1995). Psikologi Pendidikan. Gramedia.

Sustring, H. F., \& Wijaya, H. E. (2019). Taddabur Al-Quran to Decrease Anxiety Among Students Facing National Examination. International Summit on Science Technology and Humanity, 156-163.

Vallerand, R. J., Koestner, R., \& Pelletier, L. G. (2008). Reflections on Self-Determination Theory. Canadian Psychology, 49(3), 257-268. https://doi.org/10.1037/a0012804

Wahid, W. A. (2012). Cara Cepat Bisa Menghafal Al-Quran. Diva Press.

Ward, M. J. (1988). The many Facets of Self-Determination. NICHY Transition Summary, 5, 2-3.

Yatim, F. (1998). Pikun (Demensia), Penyakit Alzheimer, dan sejenisnya. Pustaka Populer Obor. 